\title{
MERECIDO PACD
}

\section{Esbeidi Lara}

Ando degradándome en un sueldo

más propinas más humillaciones más dedos corrugados

levanto (mis) restos en deliciosos platillos

el pan estaba viejo, para mí no.

Ando degradándome en lacervezafiada el cigarrobado

ando un poco más deprimente que deprimida

gracias a dios.

Ando disculpándome con sumisos

que no reclaman ni el café frío,

eso sí, déjeme buena propina,

le regalo una sonrisa y un zarandeo de nalgas

$$
\text { -iLo re-cojo señor?-. }
$$

Ando melancólica por lo que fue, por lo que no fui

y nostálgica por lo que nunca será

por lo que nunca seré.

Ando melalcohólica menos mel que alcohólica

ando vagabundeando a las cuatro de la mañana

a la una de la tarde, me duelen los pies

mañana comes carnechadaperder arrozcrudo aguadelallave

para eso trabajaste: cómelo bébelo agradécelo.

Anda mi aparato reproductorintestinal sangrando tu triunfo

yo no quería, lo lograste.

Qué importa la poesía

todo se derrumba

que nadie lo evite

que siga su rumbo

su derrumbo.
Ando algún día me engañarás con alguna [Guille

y bailarás con ella en esta misma cantina, seré tu madre sequedaencasa serás tú padre seausentapordías se va con Guille

te irás con Guille seré una Guille te irás.

¿Qué buscaba?

ando sin mí

me perdí

me olvidé

ando mel-alcohólica

ya no ando

ya no ando más. LPyH

Esbeidi Lara (Xalapa, 1996) estudia Lengua y Literatura Hispánicas y Derecho (Uv). Ha participado como creadora literaria en coloquios de lengua y literatura. El tango y el lunfardo en Gotán, de Juan Gelman, es su tema de tesis. 